\title{
Stability and Expansion or Exploitation and Stagnation? My View of Historical Osteology During the Late $1980 \mathrm{~s}$
}

\author{
Elisabeth Iregren
}

\begin{abstract}
The paper discusses both the background and future of the Swedish discipline historical osteology. Teaching as well as research is considered. A summary of the most important contributions within human and animal osteology during 1986-1990 is given. The selection is based on personal judgement as to the interest, value and quality of the papers.
\end{abstract}

Elisabeth Iregren, Institute of Archaeology, University of Lund, Sandgatan 1, S-223 50 Lund, Sweden.

\section{ORIGIN AND COLLABORATION}

The discipline of osteology incorporates important elements of major disciplines belonging to different faculties: zoology, palaeontology, physical anthropology, veterinary and human anatomy. As I see it, these sciences are among the fairy godmothers of the fairly new discipline of historical osteology. Nordic archaeology was the assisting midwife at its birth.

Many are familiar with the history of osteology in Sweden, but I nevertheless want to recapitulate some vital points. When zoologists and anatomists began to lose interest in osteology in favour of, e.g., ecology and studies at the cellular and molecular level, foresighted archaeologists supported osteological research. The close friendship and collaboration between Greta Arwidsson and the late N-G. Gejvall resulted in the formation of the Osteological Research Laboratory and the discipline of historical osteology. Thus, osteology survived under the protection of archaeology.

At Stockholm and Lund universities, historical osteology is currently closely linked to archaeology and has thus become a discipline of the faculty of humanities instead of a part of medicine or zoology. This administrative construction influences all aspects of the field, from finances to recruitment. In an international perspective the Swedish model is unique since it combines research on human and animal bones in one and the same discipline.

In Sweden, thus, zooarchaeology and physical anthropology/palaeoanthropology have always been combined during training and research within historical osteology. The term zooarchaeology (or archaeozoology) refers in the scientific world today to studies of mammals, coprolites, insects, shells or parasitic worms, e.g., all types of finds of animals in an archaeological context. Archaeologists do sometimes use the term ecofacts of these and other kinds of biological material found during archaeological excavations.

When I began training in osteology, most of the graduate students were zoologists 
and we had to study one semester of archaeology to be allowed to study at the osteological laboratory. This training was, however, also attractive to students of archaeology, who were forced to take corresponding courses in zoology.

Today, the graduate students (as well as the undergraduates) form a more homogeneous group as regards their background in training and interests being rooted in the humanities rather than the natural sciences. This may cause and probably already has caused some problems for our work and our scientific identity (Cf. Werdelin 1987).

Archaeologists today sometimes claim that collaborating with osteologists produces meagre results. This is undoubtedly true, if we examine many osteological analyses. Insufficient time and inexperience among working osteologists are some causes of this. Other obvious causes are the general lack of intimate collaboration between archaeologist and osteologist and, what is worse, a lack of knowledge and interest in the osteological work by the archaeologist. "Just give me the age and sex of the deceased" is a demand that should sound familiar to osteologists.

Some archaeologists seem to believe that a good and close collaboration is the same thing as the archaeologist directing the work of the osteologist in detail. This can be seen in many analyses, but is also apparent in both the administration of and research in osteology. Osteologists have not been natural and respected collaborators in many of the major archaeological research projects over the past decades.

Archaeology is clearly important to osteology. Archaeologists provide us with the material for our analyses and research. It is therefore obvious that we must have knowledge of cultural history to be good collaborators. But archaeologists must also gain much more insight into osteological methods and problems in order to be able to discuss osteological aims and methods and to use our results.

The problems that arise when archaeologists demand to control the aims of osteological analyses should be obvious to everyone. You can not ask for information on an issue of which you are unaware. You can not ask the osteologist to use a method you have never heard of. If the same old questions and the same traditional methods are repeated over and over again little new ground will be gained.

\section{OSTEOLOGISTS AT WORK}

Since historical osteology was founded as a university discipline in the late $1960 \mathrm{~s}$, development has been slow but steady. From an expansive introductory phase the discipline and its training and analysis work have become firmly established. Now osteology has a place in museums and universities and within the field of archaeological exploitation.

The years 1986-1990 can in my opinion be described as a time of expansion and stability within osteology. The earlier time of growing numbers of undergraduate and graduate students at the Osteological Research Laboratory of Stockholm University changed to a period of stability as two new doctoral theses were published. In 1986 Ebba During defended her thesis The Fauna of Alvastra, and a year later Per Ericson (1987) presented his thesis The Osteology of the Eider. Somateria mollissima (L.). I will return to these dissertations below.

In the Malmö-Lund region there was expansion during these years. At Malmö museum an osteologist was employed on a permanent basis for the first time. This position was designed to cover field-work as well as osteological analyses. At the University of Lund a researcher/lecturer was incorporated into the staff of the Archaeological Institute. In previous plans for the expansion of osteology and collaboration between archaeologists and osteologists, this new position was to be the first step, 
followed by a position in Göteborg and later one in Umeå (Almgren et al 1977). In Lund osteology has subsequently been taught to students of archaeology and medieval archaeology on a regular basis.

Judging from NAA, many osteological reports and studies were published in animal as well as human osteology during these years. Since NAA probably does not cover osteology and other parallel sciences to archaeology as fully as archaeology itself, the number cited is likely to be an underestimate. A great number of osteologists are involved in the work. Many studies are carried out by experienced osteologists while other reports are written by osteologists with only a few semesters' training in osteology.

Is the large number of analyses a positive sign of expansion? I think this is a serious problem within osteology. Sometimes osteological work is characterised by routine answers to common questions, by the use of simplistic methods and by little effort paid to comparisons with other analyses. This clearly adds little to our basic knowledge. I am aware that work-for-hire type of financing is not a problem that is exclusive to osteology, but this does not diminish its effects on osteological science. Only a very limited amount of work is carried out under research grants or by graduate students supported by the universities. As a result, I will mention here only a few of the papers that can be found in the four volumes of NAA, and I will choose those which I think have contributed most to our science.

\section{DISSERTATIONS WITHIN HISTORICAL OSTEOLOGY}

Both dissertations of the period belong to the field of animal osteology, although there are also many graduate students at the Osteological Research Laboratory who work on human osteology. As both volumes have been reviewed in the readily available jour- nal Fornvännen, I will mention only some points where my opinion differs from those of the reviewers.

Ebba During (1986) published an interesting volume on a minor part of the material excavated from the Alvastra pile-dwelling. A review is available in Gejvall (1987). Here I wish to stress that the bone material studied is rather small (43 of about $700 \mathrm{~kg}$ ) and that it derives from the eastern trench only. During claims that the material is "probably representative" (During 1986: abstract) but this is, however, not demonstrated. The number of bird species in the eastern trench is, e.g., not even half the number previously recorded from Alvastra (During 1986:Table 8). Further, she reports that "the horisontal and vertical distribution of different species or combination of species differ, sometimes quite remarkably" (During 1986:15). If During had presented a joint discussion of the results from the eastern and western trenches of Alvastra, this issue could have been clarified. Her analyses of the bone material from the western trench were instead made available by Browall (1986).

In his review Gejvall (1987) thoroughly discusses a new statistical method used in the dissertation. This was developed by During in collaboration with the statistician Eva Elvers. They present a method that allows a statistical estimate of the proportion of a grouped material (e. g., sheep/goat) that belongs to each of the constituent species. This is done on the basis of the proportions available in positively identified material.

During took her starting point in a monument and its bone material. Per Ericson (1987), on the other hand, dealt with a single animal species, the eider. His material consisted mainly of bone measurements and his aim was to study sexual, geographic and temporal variation. He thus succeeded in writing a volume of interest to osteologists, archaeologists and zoologists. This 
thesis was reviewed by Werdelin (1989).

\section{OTHER CONTRIBUTIONS TO}

\section{OSTEOLOGY}

My selection here is based on my personal judgement as to the value and quality of the contributions as well as my own interests.

Many studies during these years have dealt with cremation graves. Most of these are pure reports, but I especially want to mention a research project and results published by Sten and Vretemark (1988). These authors studied monumental graves with large amounts of bones in a new, very thorough way. By this means they succeeded in shedding detailed light on the burial traditions of this very high social stratum. They could, e. g., demonstrate the close parallels between the animals represented in skeletal graves and in cremations. This was also clearly shown by Vretemark (1989b) in her analysis of the warrior grave in Rickeby, Vallentuna, where the thorough excavation by Sjösvärd made parallels to the Vendel and Valsgärde graves obvious.

Another grant-financed project resulted in the article by Ericson et al (1988) on a part of the bone material from the Birka excavations of the early 1970s. The bones from this excavation were never analysed in connection with the field-work but money was later obtained from the Research Council for the Humanities and Social Sciences and applied to a limited analysis. A separate study on sea birds was also published (Ericson 1987). As one of the members of the project group, I now regret that a more extensive osteological project was never begun at that time.

In animal osteology Iregren published articles on mammal species of the Boreal forest (moose and brown bear) from palaeontological as well as archaeological deposits. Iregren treated zoological issues such as variation in tooth and bone size and evolution in shorter and longer perspectives (Iregren 1986, 1988a, Iregren et al 1990).
Ericson also worked on mammalian and bird size. He studied the size of seals in order to investigate age as well as hunting season (Knape \& Ericson 1988). Cultural history topics such as trade and religion have also been studied (Iregren 1988b, 1989).

Osteological questions concerning the Medieval period and later have above all been studied by Jonsson (1986a), Lindroth (1987), Vretemark $(1987,1989 a)$ and Sten (1988, 1989a,b). Sten's interest in castles has yielded interesting results, while Vretemark's perspective concerns production and consumption in medieval towns. Vretemark's theoretical approach is often noteworthy. Other osteologists have been working with medieval material as well, but their contributions have often had the character of simple site reports. It is important, though, that bone materials from later periods are analysed and reported as these, up till now, are extremely few.

Johannes Lepiksaar, the grand old man of animal osteology and faunal history in Sweden, published impressive summarising works. A review of the faunal history of Fennoscandia and the Baltic states was published (1986a) as well as a summary of the history of domesticated animals in Sweden (1986b). In 1988 Lepiksaar was presented with an honorary doctorate at the Faculty of Humanities at the University of Lund. On this occasion a symposium with several interesting contributions in his honour was organized (Iregren \& Liljekvist 1989).

In the volume Man and Environment, Jonsson (1988) deals in detail with Mesolithic animal finds from burials and selected parts of different sites. Another article by Jonsson (1986) treats the fish finds from the Skateholm graves only. This paper discusses the location of the fish bones (stomach region and/or outside the body) and also which species are present.

Few Swedish works deal with palaeopathology, though the journal OSSA regularly publishes within this field. The physi- 
cian Leden and Ove Persson and Evy Persson (1986) contributed, however, to our knowledge of rheumatic disorders in the Neolithic.

In this context, I must also mention the Danish odontologist and anthropologist Verner Alexandersen, who often works on Swedish archaeological material. In 1988 he published a very thorough and interesting analysis of the dentition of the Mesolithic individuals at Skateholm (Alexandersen 1988). The same graves were studied by Persson and Persson (1988a) as to their general physical anthropology. Another noteworthy contribution by Alexandersen deals with tooth size and morphology in Saami and Nordic groups (1988b).

In a third work Alexandersen (1989) studied the ethnic origin of the Battle-Axe people. His extremely important answer is that, provided that the available material is representative, no significant differences can be found between the different Neolithic cultural groups. The only identifiable differences are between Mesolithic and Neolithic populations. Both genetic traits and non heritable variation were studied.

Several other contributions to methodological issues were published during the period. Both Sjøvold and Iregren studied nonmetric traits, an important research area in Sweden since its early introduction by Sjøvold (1973, 1974). Sjøvold (1986) mainly studied the homogeneity of trait frequencies over time in one population. Iregren and collaborators (Iregren 1987/88, Iregren \& Isberg $1988 \mathrm{a}, \mathrm{b}$ ), on the other hand, tried to use non-metric traits to differentiate between Saami and Nordic populations in Scandinavia, an attempt that has been successful.

Sjøvold also worked in other areas of human osteology. He published an important article on a new method of height calculation (Sjøvold 1990). The aim was to find a method that could be used even when the sex and/or ethnic origin of the sample was unknown. The correlations obtained are, however, greater when only Caucasians are included. Sjøvold's proposal is called "the weighted line of organic correlation" and has also been used by other scientists (e.g. Oláh et al 1993). Sjøvold (1988) also contributed to one volume of the series Anthropologie, edited by Knussman, in which he presented an overview of different methods of sex-determination on the basis of several skeletal elements.

\section{FUTURE PERSPECTIVES}

The bonds of osteology to archaeology/ archaeological collections have historical causes and in my opinion they have undoubtedly saved osteology as a discipline. On the other hand, there are/will be obvious disadvantages to this close relationship. To be of use to the study of cultural history in the long run, and to develop into a true discipline of its own, osteology must continue to grow.

Osteology is a biological discipline developed out of human and animal anatomy. Our methods for evaluating archaeological complexes must be based on a firm knowledge of anatomy, physiology, growth, variation etc. of both humans and animals. This knowledge can help us to solve questions of interest to archaeologists, historians and demographers, as well as to ourselves. But if osteologists allow archaeologists to ask all the questions, these will rarely rise above the level of species, age and sex. Furthermore, the background and training of students in osteology is essential - perhaps as important as administrative links and job opportunities.

Growth within the discipline must, in my opinon, concern diversity as well as depth. Great effort should be made to induce students from biology, chemistry, geology, odontology and medicine to begin graduate studies linked to osteology. Their theses could either use only excavated osteological material or combine bone materials, to 
be used as comparative material to other kinds of material. Other themes of research ought to concentrate on methods and techniques from other disciplines and apply them to historical osteology. On the whole, knowledge of the methods and problems of neighbouring disciplines must increase among researchers and students of osteology. Great effort must be made to develop and test new methods.

Promoting graduate studies is one way of increasing diversity and skill, and starting interdisciplinary research is another. Broad research projects should be formulated and supported. Visiting scientists should be invited to give courses and to study our vast material. Regular seminars and symposia should be organised on different themes in Sweden and Scandinavia to promote collaboration. Also, our theoretical level must be raised.

It is also essential that our knowledge of living animals and living people increase. Among our Nordic colleagues in zoology and physical anthropology it is a constant complaint that we osteologists know "too much" about bones and too little about processes acting on different species today, including man. I agree with this, and I realise that we also know far too little

\section{REFERENCES}

Alexandersen, V. 1988a. Description of the human dentitions from the Late Mesolithic grave fields at Skateholm, Southern Scania. In: Larsson L. (ed.) The Skateholm project I. Man and environment. Acta Societatis Humaniorum Litterarum Lundensis 79:106-164.

- 1988b. Affinities between the 11th century Vivallen/Jämtland and Nordic and Saami groups based on tooth size and morphology. Circumpolar Health 87. Arctic Medical Research 47, suppl. 1:213-217.

- 1989. Tandforholdene i enkeltgravstid/Strids$\emptyset \mathrm{ksetid}$. Stridsyxekulturen i Sydskandinavien. about zoological ecology, vegetation, climate, human diseases, animal domestication, population genetics, etc.

To be able to fulfil these demands on our science, teachers and researchers from different disciplines must be linked to osteological research and training groups. Positions lasting, e.g., six years should be created for this purpose, so that the teachers can be long-term tutors of graduate students. Regarding publications, there must be a shift from simple site reports to real studies using new techniques and treating problems that add to basic knowledge. To be able to reach these goals we must on the one hand, teach archaeologists who order osteological work to raise their demands and, on the other hand, to define new goals. At the moment we must self-critically ask: Are there any methods and theories that are exclusively our own? Where do we stand? Where do we aim? Let us hope that stability will not be synonymous with stagnation.

\section{ACKNOWLEDGEMENT}

I cordially thank Lars Werdelin, who gave valuable comments on an earlier draft of this article.

English revised by Laura Wrang.
University of Lund, Institute of Archaeology, Report Ser. no. 36:169-180.

Almgren, B., Malmer, M.P., Stjernquist. B. \& Nordström, H-Å. 1977. Yttrande från kommitten för utredande av behovet av naturvetenskaplig service för arkeologer. Humanistisk-Samhällsvetenskapliga forskningsrådet.

Browall, H. 1986. Alvastra pålbyggnad: social och ekonomisk bas. Theses and papers in North-European Archaeology 15, Stockholm University.

During, E. 1986. The fauna of Alvastra. An osteological analysis of animal bones from a 
Neolithic pile dwelling. Ossa 12, suppl. 1 .

Ericson, P. 1987. Osteology of the eider. Somateria mollissima (L.). A study of sexual, geographic and temporal morphometric variation in the eider skeleton. Statens Historiska Museum. The Museum of National Antiquities/ Stockholm, Studies 5.

- 1987. Exploitation of seabirds in central Sweden during late Iron Age - conclusions drawn from the bird remains at Birka. Theoretical approaches to artefacts, settlement and society. Burenhult, G., Carlsson, A. Hyenstrand, Å.\& Sjøvold, T. (Eds). BAR International Series 366 (II):445-453.

Ericson, P., Iregren, E. \& Vretemark, M. 1988. Animal exploitation at Birka - a preliminary report. Fornvännen:81-88.

Gejvall, N-G. 1987. Review of During, E. 1986. The fauna of Alvastra. An osteological analysis of animal bones from a Neolithic pile dwelling. Fornvännen:228-230.

Iregren, E. 1986. Variations of tooth size of moose (Alces alces $\mathrm{L}$ ) during six millenia in Northern Sweden. Archaeozoologia, Mélanges, pp 87 97.

- 1987-88. Skelettmaterial från nyare tid på Nordkalotten. Studia Historica Septentrionalia 14 (1): 35-50. Jyväskylä.

- 1988a. Size of the Brown Bear (Ursus arctos L) in Northern Sweden during the last millenium, pp. 165-178. ArchaeoZoologia 2 (1.2.).

- 1988b. Finds of brown bear (Ursus arctos) in southern Scandinavia - indications of local hunting or trade? Trade and Exchange in Prehistory. Studies in Honour of Berta Stjernquist. Acta Archaeologica Lundensia, Ser in $8^{\circ}$, No $16: 295-308$.

- 1989. Under Frösö kyrka - ben från en vikingatida offerlund? University of Lund. Institute of Archaeology. Report Series, No 34:119-133. Iregren, E. \& Isberg, P-E. 1988a. Genetic composition and variation in Nordic populations in Middle Sweden and Middle Norway - a study of non-metric skull variants. Abstract in Tagungsbericht, "Normvarianten aus anthropologischer und humangenetischer Sicht". Biologische Gesellschaft der DDR, 15.-19. November 1987, Schloss Reinhardsbrunn/Thüringen.

- 1988b. Genetic composition and variation in Saami populations in Northern Norway compared with Nordic populations in Middle Nor- way. A study of non-metric skull variants. Circumpolar Health 87. Arctic Medical Research 47, suppl. 1:218-225.

Iregren, E. \& Liljekvist, R. (eds.) 1989. Faunahistoriska studier tillägnade Johannes Lepiksaar: University of Lund, Report Ser. No 33.

Iregren, E., Ringberg, B. \& Robertsson, A-M. 1990. The brown bear find (Ursus arctos L) from Ugglarp, southernmost Sweden - the skeleton, its age and environment. Sveriges Geologiska Undersökning, serie C Nr 824.

- 1986a. Finska gäddor och Bergenfisk - ett försök att belysa Uppsalas fiskimport under medeltid och yngre Vasatid. Från Östra Aros till Uppsala. Uppsala stads historia 7:122-139. Uppsala.

- 1986b. Fish bones in Mesolithic graves, pp. 6379. Fish and Archaeology (eds.) Brinkhuizen, D.C. \& Clason, A.T. BAR International Series 294.

- 1988. The vertebrate faunal remains from the Late Atlantic settlement Skateholm in Scania, south Sweden pp. 56-88. In: Larsson, L. (Ed). The Skateholm project I. Man and environment. Acta Regiae Societatis Humaniorum Litterarum Lundensis 79.

Knape, A. \& Ericson, P. 1988. Stora Förvar - kontinuitet och förändring $i$ ett resursutnyttjande. Gotländskt arkiv 60:31-38.

Lepiksaar, J. 1986a. The Holocene history of theriofauna in Fennoscandia and Baltic countries. Striae 24:51-70.

- 1986b. Från vilda djur till husdjur. Fataburen: 9-26.

Leden I., Persson, E. \& Persson, O. 1986. Peripheral polyarthritis in two Neolithic skeletons. OSSA 12: 79-88.

Lindroth, B. 1987. Ystadsprojektet - diskussion kring osteologiskt material från några medeltida landsbyar. Meta 3:33-40.

Oláh, S., Pacciani \& Cencetti, S. 1993. Anthropological examination of the Etruscan bone material from Magliano in Toscana, Cancellone I, Grosseto, Italy. Intenational Journal of Anthropology 8:155-161.

Persson, O. \& Persson, E. 1988. Anthropological report concerning the interred Mesolithic populations from Skateholm, Southern Sweden. In: Larsson, L. (Ed). The Skateholm project I. Man and environment. Acta Societatis Humaniorum Litterarum Lundensis 79:89-105.

Sjøvold, T. 1973. The occurrence of minor, non- 
metric variants in the skeleton and their quantitative treatment for population comparisons. HOMO 24:204-233.

- 1974. Some aspects of physical anthropology on Gotland during Middle Neolithic times, pp. 176-210. In: Janzon, G. O. Gotlands mellanneolitiska gravar. Studies in North-European Archaeology 6. Diss. Stockholm.

- 1986. Infraopulation distances and genetics of non-metric traits, pp. 81-93. In: Herrmann, B. (Ed). Innovative Trends in der Prähistorischen Anthropologie. Mitteilungen der Berliner Gesellschaft für Anthropologie, Ethnologie und Urgeschichte, Bd 7.

- 1988. Geschlechtsdiagnose am Skelett, pp. 444-480. In: Knussman, R. (Ed). Anthropologie. Handbuch der vergleichenden Biologie des Menschen. Band I. Gustav Fischer Verlag, Stuttgart-New York.

- 1990. Estimation of stature from long bones utilizing the line of organic correlation. $\mathrm{Hu}$ man Evolution 5:431-447.

Sten, S. 1988. Kosthållning och pälsjakt - osteologins vittnesbörd, pp. 149-162. Bondeplägarens borg. Eds. Mogren, M. \& Svensson, K. RAÄ.

- 1989a. Två dalaborgars ekonomiska och sociala struktur belyst av det osteologiska materialet. Den medeltida borgen (ed.) J. Melander. pp. 5l-56.

- 1989b. Husdjurshållning, jakt och fiske i Silbojokk - en osteologisk analys av djurbenen, pp. 167-178. Silvret från Nasafjäll. Arkeologi vid Silbojokk. Eds. Awebro, K., Björkenstam, N., Norrman, J., Petersson, S., Roslund, Y., Sten, S. \& Wallquist, E. RAÄ.

Sten, S. \& Vretemark, M. 1988. Storgravsprojektet - osteologiska analyser av yngre järnålderns benrika brandgravar. Fornvännen:145-156.

Vretemark, M. 1987. Djurben i väst- och mellansvenska städer - en översikt av kunskapsläget. Meta 3:6-15.

- 1989a. Medeltida djurben - ett ofullständigt utnyttjat källmaterial. Meta 2:3-13.

- 1989b. Djuroffer för en storman - en osteologisk analys. Rä̈-SHMm. Rapport UV 1989:34-40.

Werdelin, L. 1987. Några reflektioner kring svensk osteologi. Meta 3:52-56.

- 1989. Review of Ericson, P. G. P.1987. Osteology of the Eider. Somateria mollissima (L.). A study of sexual, geographic and temporal morphometric variation in the eider skeleton. Fornvännen:100-102. 